\title{
MODAL SOSIAL DAN PARTISIPASI MASYARAKAT DALAM PEMBANGUNAN DESA WISATA TAMANSARI DI KABUPATEN BANYUWANGI
}

\section{Social Capital dan Community Participation of Tamansari Tourism Development in Banywwangi District}

\author{
Eka Puspitaningrum ${ }^{1)}$, Djuara P. Lubis ${ }^{1)}$ \\ ${ }^{1)}$ Departemen Sains Komunikasi dan Pengembangan Masyarakat, Fakultas Ekologi Manusia, \\ Institut Pertanian Bogor, Darmaga Bogor 16680, Indonesia \\ E-mail: ekapuspitaningrum33@gmail.com; djuaralu@apps.ipb.ac.id
}

\begin{abstract}
Development can not be defined just only in terms of increasing access to resources or improving welfare, but also concerning how the benefits of the development are perceived by society as the main of development subject, especially in the tourism village developement. In implementation, the tourism village development requires social capital and active participation from the community. This research aims to identify the correlation of social capital and community participation in the tourism village development in Tamansari Village, Banyuwangi District. The results of research through the statistical tests showed that there is a strong correlation between the level of community participation with the level of tourism village development, and there is a sufficient correlation between the level of social capital with the level of community participation. This is due to the high driving factors of participation and social capital owned by the community, so that the community has a good involvement in the implementation of the tourism village development in Tamansari Village.
\end{abstract}

Keyword : driving participation factors, ocsial capital, participation, tourism village development

\begin{abstract}
ABSTRAK
Pembangunan tidak dapat didefinisikan hanya dalam arti peningkatan akses terhadap suatu sumber daya ataupun peningkatan kesejahteraan, tetapi juga menyangkut pada bagaimana manfaat itu dirasakan oleh masyarakat sebagai subjek pembangunan terutama dalam pembangunan desa wisata. Dalam pelaksanaannya, pembangunan desa wisata membutuhkan modal sosial dan partisipasi aktif dari masyarakat. Penelitian ini bertujuan untuk mengidentifikasi hubungan modal sosial dan partisipasi masyarakat dalam pembangunan desa wisata di Desa Tamansari Kabupaten Banyuwangi. Hasil penelitian yang diperoleh melalui uji statistik menunjukkan bahwa terdapat hubungan kuat antara tingkat partisipasi masyarakat dengan tingkat pembangunan desa wisata dan terdapat hubungan yang cukup antara tingkat modal sosial dengan tingkat partisipasi masyarakat. Hal ini dikarenakan tingginya faktor pendorong partisipasi serta modal sosial yang dimiliki masyarakat, sehingga masyarakat memiliki keterlibatan yang baik dalam pelaksanaan pembangunan desa wisata di Desa Tamansari.
\end{abstract}

Kata kunci: faktor pendorong partisipasi, modal sosial, partisipasi, pembangunan desa wisata

\section{PENDAHULUAN}

Pembangunan desa bukan merupakan hal yang baru lagi di Indonesia. Pembangunan tidak dapat didefinisikan hanya dalam arti peningkatan akses terhadap suatu sumber daya ataupun peningkatan kesejahteraan, tetapi juga menyangkut pada bagaimana manfaat itu dirasakan oleh masyarakat. Pembangunan dapat juga diartikan sebagai suatu rangkaian usaha pertumbuhan dan perubahan yang berencana dan dilakukan secara sadar oleh suatu bangsa, negara, dan pemerintah (Siagian 1994). Upaya yang selaras dari pemerintah, negara, dan masyarakat akan memberikan dampak yang baik untuk pembangunan desa salah satunya adalah pembangunan desa wisata.

Desa wisata dapat didefinisikan sebagai wilayah pedesaan dengan suasana alami dalam struktur ruang, arsitektur bangunan, maupun kehidupan sosial-budaya masyarakatnya, serta mampu menyediakan komponen-komponen kebutuhan pokok seperti akomodasi, makanan dan minuman, 
cindera mata, dan atraksi-atraksi wisata bagi wisatawan (Pitana 2005). Dalam pelaksanaannya, desa wisata membutuhkan partisipasi masyarakat, dan untuk berpartisipasi, masyarakat desa membutuhkan modal-modal dalam memenuhi dan menjalankan kehidupannya.

Salah satu modal yang sangat diperlukan adalah modal sosial (Masik 2005). Modal sosial didefinisikan sebagai serangkaian nilai-nilai atau norma-norma informal yang dimiliki bersama di antara para anggota suatu kelompok yang memungkinkan terjalinnya kerjasama di antara mereka (Fukuyama 1995). Dari sudut pandang sosiologi, elemen utama dalam modal sosial mencakup norms, reciprocity, trust, dan network (Subejo 2004). Partisipasi masyarakat dalam jaringan, resiprositas, kepercayaan norma sosial, sifat keumuman pemilikan, dan sikap warga yang proaktif sangat dibutuhkan oleh modal sosial agar dapat beroperasi dengan baik terutama dalam kegiatan pembangunan desa. Pengelolaan dengan mengedepankan partisipasi dipercaya akan menumbuhkan rasa memiliki (sense of belonging) (Kusumastuti 2015).

Nasdian (2006) memaparkan bahwasanya partisipasi dalam pengembangan komunitas harus menciptakan peranserta yang maksimal dengan tujuan agar semua orang dalam masyarakat tersebut dapat dilibatkan secara aktif pada proses dan kegiatan masyarakat. Kusumastuti (2015) menambahkan bahwa pengelolaan kegiatan pembangunan yang mengedepankan partisipasi masyarakat desa memiliki prinsip kerja berupa gotong royong dan bekerjasama sehingga dipercaya akan menumbuhkan rasa saling memiliki.

Desa Tamansari terletak di Kabupaten Banyuwangi dan merupakan salah satu desa yang letaknya di sekitar Kawasan Kawah Ijen. Pada tahun 2016 Desa Tamansari ditetapkan sebagai salah satu desa wisata di Banyuwangi. Masyarakat merupakan komponen utama dalam suatu pembangunan, terutama dalam pembangunan desa wisata. Pembangunan Desa Tamansari sebagai desa wisata membutuhkan peranserta dari masyarakat.

Berdasarkan kondisi tersebut perlu dipelajari lebih lanjut untuk melihat bagaimana modal sosial dan partisipasi yang dimiliki masyarakat Desa Tamansari dalam pembangunan desa wisata. Selain itu, perlu juga melihat bagaimana peranan dari variabel faktor pendorong partisipasi dengan partisipasi masyarakat, dan karakteristik individu dengan modal sosial dan faktor pendorong partisipasi yang ada pada masyarakat. Untuk mengetahui keterkaitan dari variabel-variabel tersebut menyebabkan perlunya pengujian terhadap hubungan dari karakteristik individu dengan tingkat modal sosial dan faktor pendorong partisipasi, serta pengujian hubungan dari partisipasi masyarakat dengan modal sosial dan faktor pendorong partisipasi yang dimiliki masyarakat.

\section{PENDEKATAN TEORITIS}

\section{Modal Sosial}

Masyarakat di suatu daerah akan memiliki perbedaan dalam berbagai bidang, salah satunya dalam bidang pembangunan. Ketersediaan modal merupakan salah satu faktor penjelas adanya perbedaan tersebut (Masik 2005). Nasdian (2014) mendefinisikan modal sosial merupakan suatu dampak sosial yang memberikan perubahan yang positif yang dapat dirasakan oleh anggota kelompok dengan adanya variabel-variabel seperti kepercayaan (trust), kerjasama (cooperation) serta variabel jejaring (networking).

Menurut Bourdie dalam Harsono (2014) modal sosial sebagai sumber daya aktual dan potensial yang dimiliki oleh seseorang berasal dari jaringan sosial yang terlembagakan serta berlangsung terusmenerus dalam bentuk pengakuan dan perkenalan timbal balik atau dengan kata lain keanggotaan dalam kelompok sosial yang memberikan kepada anggotanya berbagai bentuk dukungan kolektif. Putnam (1993) menegaskan bahwa modal sosial seperti trust (rasa saling percaya), norm (hubungan saling timbal balik), dan jaringan kerja, memudahkan terjadinya koordinasi dan kerja sama untuk kemanfaatan bersama.

Frekuensi pertemuan dalam masyarakat merupakan suatu keunggulan dalam pengelolaan modal sosial di dalam masyarakat (Cahyono dan Adhiatma 2012). Batasan-batasan yang dikemukaan oleh banyak ahli mengenai modal sosial sangat beragam. Dari banyaknya batasan yang dikemukakan tersebut, Syahyuti (2008) melihat beberapa ahli lebih menekankan pada pentingnya trust, sebagaian lagi sosial network dan behavioral norms dalam modal sosial.

\section{Partisipasi}

Partisipasi merupakan salah satu aspek yang paling penting di dalam masyarakat yang dapat mendukung 
keberhasilan program pengembangan masyarakat. Nasdian (2014) mendefinisikan partisipasi sebagai suatu proses aktif dan inisiatif yang diambil dan dibimbing oleh cara berfikir mereka sendiri, dengan menggunakan sarana dan proses melalui lembaga dan mekanisme di mana mereka dapat menegaskan kontrol secara efektif. Titik tolak dari partisipasi tersebut adalah memutuskan, bertindak, dan merefleksikan tindakan tersebut sebagai subjek yang sadar.

Tingkatan partisipasi merupakan derajat tingkat keterlibatan masyarakat dalam sebuah program yang terlihat dari kesempatan masyarakat untuk terlibat dan mempengaruhi jalannya program (Oktavia dan Saharuddin 2013). Nasdian (2006) menjelaskan bahwa partisipasi dalam pengembangan komunitas harus menciptakan peranserta yang maksimal dari masyarakat selaku subjek dari kegiatan dengan tujuan agar semua orang dalam masyarakat tersebut dapat dilibatkan secara aktif pada proses dan kegiatan masyarakat dalam setiap tahapan yaitu tahap perencanaan, pelaksanaan, dan menikmati hasil, dan evaluasi. Adapun tahapan patisipasi dalam desa wisata dapat dibagi ke dalam tahapan tahap perencanaan, pelaksanaan, dan pengawasan (Dewi et.al 2012).

\section{Faktor Pendorong Partisipasi}

Dalam pelaksanaannya, partisipasi seseorang akan dipengaruhi oleh faktor-faktor baik faktor internal maupun faktor eksternal yang dapat mendorong semakin baik atau semakin buruknya kadar partisipasi seseorang. Menurut Ariyani (2007) terdapat tiga prasyarat agar seseorang dapat berpartisipasi dalam pembangunan yaitu adanya kesadaran pada diri yang bersangkutan tentang adanya kesempatan, adanya kemauan yang merupakan sikap positif terhadap sasaran partisipasi, serta dukungan oleh kemampuan berinisiatif untuk bertindak dengan komitmen. Menurut Slamet (2003) partisipasi masyarakat dalam sebuah proses pembangunan akan terwujud nyata apabila faktorfaktor yang mendukungnya dapat terpenuhi.

Faktor pendukung partisipasi menurut Slamet (2003), yaitu : a) adanya kesempatan, yang diartikan adanya suasana atau kondisi lingkungan yang disadari seseorang bahwa dirinya memiliki peluang untuk berpartisipasi; b) adanya kemauan, diartikan terdapat adanya sesuatu yang mendorong dan menumbuhkan minat ataupun sikap mereka sehingga termotivasi untuk berpartisipasi; c) adanya kemampuan, yang berarti terdapatnya kesadaran atau keyakinan pada dirinya bahwa dia memiliki kemampuan untuk berpartisipasi melalui pikiran, tenaga, waktu, atau sarana meterial lainnya.

\section{Pembangunan Desa Wisata}

Negara. Wilayah pedesaan sering dikaitkan dengan keterbelakangan ataupun kemiskinan. sehingga pemerintah mencanangkan pembangunan pariwisata dengan konsep desa wisata sebagai salah satu upaya yang diharapkan dapat dirasakan manfaatnya oleh penduduk desa (Permanasari 2011).

Pembangunan juga menyangkut pada bagaimana manfaat itu dirasakan oleh masyarakat. Menurut Kartasasmita (1994) pembangunan adalah suatu proses perubahan ke arah yang lebih baik melalui upaya yang dilakukan secara terencana. Pembangunan dapat juga diartikan sebagai suatu rangkaian usaha pertumbuhan dan perubahan yang berencana dan dilakukan secara sadar oleh suatu bangsa, negara, dan pemerintah (Siagian 1994). Partisipasi aktif dan positif dari masyarakat salah satunya ditunjukkan dengan tetap terjaganya lingkungan desa wisata tersebut. Adapun dampak atau manfaat dari pembangunan desa tersebut adalah meningkatkan pendapatan, serta terciptanya lapangan pekerjaan bagi masyarakat sekitar (Dewi et al. 2013). Selain itu, menurut Dewi et al. (2013) partisipasi masyarakat dalam pembangunan merupakan hal yang penting ketika diletakkan atas dasar keyakinan bahwa masyarakatlah yang paling tahu apa yang dibutuhkan.

\section{Kerangka Pemikiran}

Modal sosial merupakan hal yang dibutuhkan dalam masyarakat karena modal sosial dapat mengurangi dampak dari ketidaksempurnaan kehidupan masyarakat dengan adanya pengorganisasian peran (rules) yang diekspresikan dalam hubungan personal (personal relationship), kepercayaan (trust), dan common sense dalam tanggung jawab bersama. Oleh karena itu, modal sosial akan meningkatkan peranan ataupun keikutsertaan masyarakat dalam suatu pencapaian tujuan. Namun, seringkali modal sosial dipengaruhi oleh karakteristik individu itu sendiri.

Pembangunan desa wisata memiliki tujuan yang baik untuk desa maupun untuk masyarakatnya, sehingga partisipasi masyarakat sangat dibutuhkan dalam setiap tahap pelaksanaan pembangunan desa wisata. Partisipasi masyarakat merupakan proses aktif, inisiatif diambil oleh warga komunitas sendiri, 
dibimbing oleh cara aktif berfikir mereka sendiri, dengan menggunakan sarana dan proses (lembaga dan mekanisme) di mana mereka dapat menegaskan kontrol secara efektif (Nasdian 2014). Seringkali partisipasi masyarakat dipengaruhi oleh faktorfaktor, seperti kemauan, kesempatan, dan kemampuan (Slamet 2003) dan juga oleh modal sosial yang dimiliki oleh masyarakat (Kusumastuti 2015).

Putnam (1993) menyatakan bahwa modal sosial terdiri dari komponen kepercayaan, norma, dan jaringan yang dapat menciptakan dan meningkatkan hubungan positif di dalam suatu masyarakat. Komponen yang terdapat di dalam modal sosial dapat mengatur hubungan di dalam suatu masyarakat, sehingga dapat meningkatkan kepedulian masyarakat dan memberikan pengaruh pada keterlibatan aktif atau partisipasi masyarakat dalam pembangunan desa wisata. Saputro (2012) memaparkan bahwa modal sosial di dalam suatu masyarakat dapat dipengaruhi oleh kelompok variabel individu yaitu tingkat pendidikan, lama tinggal, dan umur.

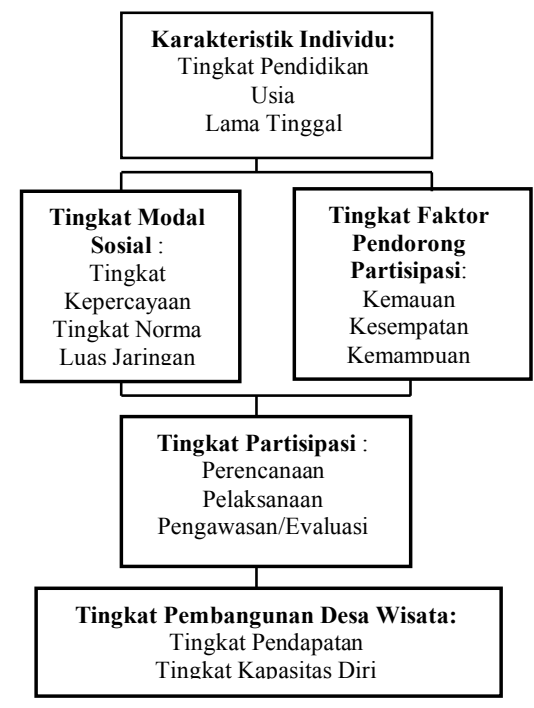

Keterangan :

— : Berhubungan

Gambar 1 Kerangka pemikiran modal sosial dan partisipasi masyarakat dalam pembangunan desa wisata di Banyuwangi

Pembangunan desa wisata memiliki tujuan untuk memberikan manfaat bagi para pelakunya. Pembangunan desa wisata harus berkelanjutan sehingga dalam pengembangannya harus berbasis masyarakat. Pengembangan desa wisata berbasis masyarakat. Desa. Dewi et al. (2013) menambahkan bahwa pembangunan desa wisata bagi masyarakat bertujuan untuk menurunkan angka kemiskinan, meningkatkan pendapatan masyarakat, meningkatkan keterampilan masyarakat ataupun individu. Namun, pada kenyataannya seringkali masyarakat belum dilibatkan dalam suatu pembangunan desa wisata. Oleh karena itu, perlunya dikaji bagaimana modal sosial dan pastisipasi masyarakat di Desa Tamansari untuk ikutserta dalam pembangunan desa wisata di Desa Tamansari.

\section{METODE PENELITIAN}

Penelitian yang dilakukan untuk mengidentifikasi hubungan "Modal Sosial dan Partisipasi Masyarakat dalam Pembangunan Desa Wisata Tamansari di Kabupaten Banyuwangi" menggunakan pendekatan kuantitatif, dengan data kuantitatif yang didukung dengan data kualitatif. Data kuantitatif diperoleh melalui metode survei melalui instrumen kuesioner yang diberikan kepada responden. Data kualitatif diperoleh melalui metode wawancara mendalam kepada informan yang memiliki peranan penting dengan menggunakan panduan pertanyaan. Informasi yang diperoleh dari informan digunakan untuk menyempurnakan data dari hasil kuesioner sebagai penguat dari data kuantitatif.

Penelitian ini menggunakan metode penelitian survei. Pemilihan lokasi ini dilakukan secara sengaja (purposive) yaitu di Desa Tamansari, Kecamatan Licin, Kabupaten Banyuwangi, Provinsi Jawa Timur dengan pertimbangan bahwa desa tersebut merupakan salah satu desa yang dijadikan sebagai desa wisata oleh Pemerintah Daerah Banyuwangi dan menjadi salah satu desa binaan BCA dan baru dijadikan desa wisata. Penelitian ini dilakukan pada bulan Maret 2017 sampai April 2017.

Jumlah responden pada penelitian adalah 43 responden yang diambil menggunakan rumus slovin dengan sebaran responden pada brand kampung wisata Desa Tamansari, yaitu Kampung Penambang (Dusun Kebundadap), Kampung Bunga (dusun Jambu), dan Kampung Susu (Dusun Ampelgading). Unit analisis yang diambil adalah individu. Pemilihan informan dan rsponden dalam penelitian ini dilakukan secara langsung dan purposive (sengaja).

Penelitian ini mempunyai dua jenis data yang diolah dan dianalisis, yaitu data kuantitatif dan data 
kualitatif. Data kuantitatif diolah menggunakan aplikasi Microsoft Excell 2013 dan SPSS for windows 21 untuk membantu uji statistik dengan menggunakan Rank Spearman. Data kuantitatif dikumpulkan dengan menggunakan kuesioner. Kuesioner dalam penelitian ini digunakan sebagai instrumentasi penelitian yang diujikan terlebih dahulu kepada 10 orang laki-laki dan perempuan yang bekerja sebagai penyedia jasa wisata di Desa Tamansari untuk mengetahui seberapa baik hasil pengukuran di lapangan dengan melihat hasil dari validitas dan reliabilitas. Data kualitatif didapatkan melalui wawancara mendalam kepada informan untuk mendapat data mengenai keterlibatan masyarakat dalam pembangunan desa wisata. Data kualitatif dianalisis melalui tiga tahap yaitu reduksi data, penyajian data, dan verifikasi.

\section{HASIL DAN PEMBAHASAN}

\section{Program Pembangunan dan Pengembangan Desa Wisata di Desa Tamansari}

Pada awalnya masyarakat belum mengetahui apa yang harus mereka lakukan dengan semakin banyaknya pengunjung atau wisatawan yang datang berkunjung ke Kawah Ijen namun tidak pernah melihat Desa Tamansari. Selatelah itu, keberadaan CSR BCA melihat potensi yang dapat dikembangkan dalam masyarakat, lalu sebagai baktiya untuk masyarakat, pihak BCA menjadikan Desa Tamansari sebagai desa wisata binaan BCA di daerah Banyuwangi.

Desa Tamansari diresmikan menjadi desa wisata pada tanggal 19 Mei 2016. Peresmian dilakukan dengan adanya pemotongan pita bersama masyarakat dan pihak BCA sekaligus peresmian Gedung Tourism Information Centre (TIC) dan Rumah Makan Oseng. Sebelum ditetapkan menjadi desa wisata, BCA bersama beberapa perwakilan masyarakat Desa Tamansari mengadakan kegiatan brechmarking ke Desa Pentingsari dan Desa Bejiharjo. Kegiatan ini bertujuan untuk melihat bagaimana desa-desa terssebut dapat mengembangkan potensi desa mereka menjadi daya tarik wisata yang dapat mendatangkan pengunjung.

Tourism Information Centre (TIC) merupakan bangunan yang diberikan oleh pihak BCA sebagai salah satu tempat yang diharapkan dapat menunjang keberlangsungan Desa Wisata Tamansari. Selain itu wisatawan juga dapat mencicipi beragam makanan khas Banyuwangi di Rumah Oseng.
Pembentukan Desa Tamansari sebagai salah satu desa wisata di Banyuwangi ditanggapi positif oleh masyarakat. Harapannya, dengan dijadikannya Desa Tamansari sebagai salah satu desa wisata binaan CSR BCA dapat meningkatkan kesejahteraan masyarakat, tidak hanya masalah keuangan, namun juga pengembangan dan kapasitas diri dari masyarakat Desa Tamansari dan bagaimana mereka dapat menjual potensi desa mereka sendiri. Rapat perencanaan pertama dilaksanakan bersama dengan pihak BCA, pemerintah desa, dan beberapa perwakilan masyarakat yang diadakan di Kantor Desa Tamansari. Rapat tersebut dilaksanakan untuk membicarakan peresmian Desa Tamansari sebagai salah satu desa binaan yang akan dijadikan desa wisata. Setelah itu masyarakat menggali potensipotensi desa yang dapat dijadikan daya tarik pengunjung agar singgah di Desa Tamansari. Akhirnya, dengan usaha bersama, Desa Tamansari membagi tiga brand wisata sesuai dengan potensi daerah dan masyarakatnya sesuai dengan keputusan bersama. Kampung Wisata Tamansari dibagi kedalam tiga bagian, yaitu Kampung Penambang di Dusun Kebundadap, Kampung Bunga di Dusun Jambu, dan Kampung Susu di Dusun Ampelgading.

\section{Karakteristik Responden}

Karakteristik responden didapatkan dari hasil temuan data primer di lapangan. Jumlah responden yang diteliti adalah sebanyak 43 responden. Karakteristik responden dalam penelitian ini dilihat berdasarkan usia, tingkat pendidikan dan lama tinggal responden.

Berdasarkan Tabel 1, masyarakat di Desa Tamansari sebagian besar memiliki pendidikan yang rendah yaitu sekitar tamat SD dan tamat SLTP dikarenakan pada zaman dulu akses untuk bersekolah sangat sulit baik sarana dan prasaran yang tidak memadai maupun kemampuan finansial masyarakat tidak mencukupi. Selain itu, mereka lebih memilih untuk bertai, menambang belerang, berdagang, dan menjadi buruh di pabrik perkebunan untuk mencukupi kehidupan mereka.

Pada tingkat usia, responden pada penelitian ini berada pada kategori muda yaitu pada usia $<39$ tahun, menengah yaitu pada usia 39-51 tahun, dan tua pada usia $>51$ tahun. Masyarakat di Desa Tamansari sebagaian besar termasuk kepada kategori usia menengah. Hal tersebut dikarenakan, masyarakat dengan usia muda lebih memilih merantau ke luar kota seperti Bali, Jogja, Bogor, 
Bandung, dan Surabaya untuk bekerja sebagai buruh dikarenakan kurang tersedianya lapangan pekerjaan di daerah asal mereka. Masyarakat dengan usia menengah lebih memilih untuk bekerja di desa ataupun di kota Banyuwangi, sehingga mereka dapat lebih bannyak memberikan kontribusinya untuk desa.

Tabel 1 Jumlah dan persentase responden berdasarkan Karakteristik Individu tahun 2017

\begin{tabular}{|c|c|c|c|}
\hline $\begin{array}{l}\text { Karakteristik } \\
\text { Individu }\end{array}$ & Kategori & $\begin{array}{c}\text { Jumlah } \\
\text { (n) }\end{array}$ & $\begin{array}{c}\text { Persentase } \\
(\%)\end{array}$ \\
\hline \multirow{4}{*}{ Pendidikan } & $\begin{array}{l}\text { Tidak Tamat } \\
\mathrm{SD} / \text { Tamat } \\
\mathrm{SD} / \text { Sederajat }\end{array}$ & 22 & 51 \\
\hline & $\begin{array}{l}\text { Tamat } \\
\text { SLTP/Sederajat }\end{array}$ & 15 & 35 \\
\hline & $\begin{array}{l}\text { Tamat } \\
\text { SLTA/Sederajat }\end{array}$ & 6 & 14 \\
\hline & Total & 43 & 100 \\
\hline \multirow{4}{*}{ Usia } & $\begin{array}{l}\text { Muda (<39 } \\
\text { tahun) }\end{array}$ & 11 & 26 \\
\hline & $\begin{array}{l}\text { Menengah (40- } \\
51 \text { tahun) }\end{array}$ & 28 & 65 \\
\hline & Tua ( $>51$ tahun) & 4 & 9 \\
\hline & Total & 43 & 100 \\
\hline \multirow{4}{*}{$\begin{array}{l}\text { Lama } \\
\text { Tinggal }\end{array}$} & $\begin{array}{l}\text { Baru }(\leq 28 \\
\text { Tahun })\end{array}$ & 14 & 33 \\
\hline & $\begin{array}{l}\text { Sedang (29-47 } \\
\text { Tahun) }\end{array}$ & 23 & 53 \\
\hline & $\begin{array}{l}\text { Lama }(\geq 48 \\
\text { Tahun) }\end{array}$ & 6 & 14 \\
\hline & Total & 43 & 100 \\
\hline
\end{tabular}

Lama tinggal adalah jumlah tahun yang dihabiskan oleh seseorang untuk tinggal dan menetap di suatu wilayah. Lama tinggal masyarakat di Desa Tamansari dikategorikan ke dalam tiga kategori yang dikategorikan sesuai dengan data yang diperoleh di lapangan yaitu kategori baru dengan lama tinggal $\leq 28$ tahun, sedang dengan kategori 29 tahun-47 tahun, dan lama dengan kategori $\geq 48$ tahun. Bedasarkan Tabel 1, masyarakat Desa Tamansari pada awalnya merupakan tempat tinggal para migran-migran suku Madura dan suku Jawa yang merantau dan mencoba mencari peruntungan mereka di daerah Banyuwangi sehingga masyarakatmasyarakat yang sekarang tinggal di Desa Tamansari mayoritas sudah tinggal di Desa Tamansari sejak mereka lahir.

\section{Modal Sosial}

Modal sosial merupakan modal yang dibutuhkan oleh individu agar mampu membangun hubungan- hubungan dalam suatu kehidupan bermasyarakat. Pembahasan modal sosial dalam penelitian ini difokuskan pada kepercayaan, norma, dan jaringan sosial yang membantu masyarakat untuk bersosialisasi dan memenuhi kebutuhan hidupnya, serta untuk membantu masyarakat menjalankan suatu kegiatan maupun program bersama. Penelitian ini menjelaskan hasil identifikasi unsur-unsur modal social yang diterapkan oleh masyarakat Desa Tamansari dalam menjalakankan kehidupannya dan untuk mengetahui peran modal sosial dalam mendukung partisipasi masyarakat pada pembangunan desa wisata di Desa Tamansari. Jumlah dan persentase responden berdasarkan tingkat modal sosial pada brand kampung masyarakat Desa Tamansari disajikan pada Tabel 2.

Tabel 2 Jumlah dan persentase responden berdasarkan tingkat modal sosial pada brand kampung masyarakat Desa Tamansari tahun 2017

\begin{tabular}{lcc}
\hline \multicolumn{1}{c}{ Modal Sosial } & Jumlah $(\mathrm{n})$ & Persentase (\%) \\
\hline Kp. Penambang & & \\
Rendah & 1 & 9 \\
Sedang & 5 & 12 \\
Tinggi & 11 & 65 \\
\hline Total & 18 & 100 \\
\hline Kp. Bunga & & \\
Rendah & 3 & 21 \\
Sedang & 6 & 43 \\
Tinggi & 5 & 36 \\
\hline Total & 14 & 100 \\
\hline Kp. Susu & & \\
Rendah & 0 & 0 \\
Sedang & 5 & 42 \\
Tinggi & 7 & 58 \\
\hline Total & 12 & 100 \\
\hline
\end{tabular}

Berdasarkan Tabel 2, tingkat modal sosial yang dimiliki oleh masyarakat di Kampung Wisata Tamansari di Desa Tamansari pada setiap brand kampung menunjukkan hasil yang berbeda. Tingkat modal sosial pada kategori tinggi berada pada Kampung Penambang yaitu sebesar 65 persen dan diikuti oleh Kampung Susu sebesar 58 persen, sedangkan pada Kampung Bunga modal sosial yang dimiliki masyarakat termasuk ke dalam kategori sedang yaitu sebesar 43 persen. Tingginya modal sosial di Kampung Penambang terjadi karena masyarakat pada kampung ini memiliki intensitas bertemu yang lebih banyak dibandingkan dengan kampung lainnya, sehingga memungkinkan interaksi sosial yang lebih sering dibandingkan dengan masyarakat di kampung lainnya. Selain itu, jadwal 
kumpul bersama yang diadakan di Kampung Penambang terbilang cukup rutin, sehingga masyarakat dapat lebih sering berinteraksi dan berdiskusi. hal tersebut juga dikarenakan mayoritas masyarakat di Kampung Penambang memiliki matapencaharian yang relatif sama.

\section{Kepercayaan}

Kepercayaan merupakan bentuk dari kesediaan seseorang untuk mengambil resiko dengan adanya timbal balik yang diberikan. Kepercayaan yang terjalin di antara individu dapat memberikan dampak yang baik untuk keberlangsungan hidup bermasyarakat. Kepercayaan di antara masyarakat dapat terlihat dari bagaimana cara mereka berinteraksi satu sama lain dalam memenuhi kebutuhan mereka. Kepercayaan yang terjalin di antara masyarakat jika diidentifikasi lebih mendalam sebenarnya menunjukkan nilai yang berbeda pada setiap kampung. Hal tersebut dapat terlihat pada Tabel 3.

Tabel 3 Jumlah dan persentase tingkat kepercayaan masyarakat berdasarkan brand kampung wisata Desa Tamansari tahun 2017

\begin{tabular}{lcc}
\hline \multicolumn{1}{c}{ Kepercayaan } & Jumlah $(\mathrm{n})$ & Persentase (\%) \\
\hline Kp. Penambang & & \\
Rendah & 5 & 29 \\
Sedang & 4 & 24 \\
Tinggi & 8 & 47 \\
\hline Total & 17 & 100 \\
\hline Kp. Bunga & & \\
Rendah & 2 & 14 \\
Sedang & 5 & 36 \\
Tinggi & 7 & 50 \\
\hline Total & 14 & 100 \\
\hline Kp. Susu & & \\
Rendah & 0 & 0 \\
Sedang & 4 & 33 \\
Tinggi & 8 & 67 \\
\hline Total & 12 & 100 \\
\hline
\end{tabular}

Tabel 3 menunjukkan bahwa tingkat kepercayaan tertinggi berada pada Kampung Susu, yaitu sebesar 67 persen. Hal ini dikarenakan jumlah masyarakat termasuk ke dalam kategori kelompok kecil, sehingga memungkinkan terjadinya hubungan kepercayaan yang tinggi karena hubungan antar masyarakat lebih intensif. Selain itu, masyarakat Kampung Susu memiliki keterikatan yang baik dengan kepala desa ataupun kepala dusunnya. Masyarakat tidak segan untuk meminjam kepada masyarakat lainnya, kepala dusun, ataupun kepala desa ketika mereka membutuhkan bantuan, dan mereka memiliki perasaan percaya ketika harus menitipkan barang dagangan, atau ternak mereka kepada tetangga ataupun kerabat ketika jam istirahat ataupun ketika pergi ke luar kota

\section{Norma}

Norma merupakan sekumpulan aturan yang telah disepakati dan diharapkan akan dipatuhi masyarakat dalam suatu entitas sosial tertentu. Norma biasanya terbentuk sendiri oleh masyarakat, di mana norma diyakini dapat menjadi suatu batasan yang dapat mengatur pola hidup mereka. Norma berperan sebagai sebagai kontrol yang dapat mengatur masyarakat agar bertindak sesuai dengan kesepakatan bersama. Khususnya pada masyarakat yang bekerja dalam bidang jasa, norma mampu mengatur kepatuhan warga terhadap aturan-aturan yang ditetapkan dan mampu bertindak sebagai kontrol agar pelaksanan kegiatan tidak menimbulkan konflik di dalam masyarakat. Jumlah dan persentase tingkat norma masyarakat berdasarkan brand kampung Desa Tamansari disajikan pada Tabel 4.

Tabel 4 Jumlah dan persentase tingkat norma masyarakat berdasarkan brand kampung wisata Desa Tamansari tahun 2017

\begin{tabular}{lcc}
\hline \multicolumn{1}{c}{ Norma } & Jumlah (n) & Persentase (\%) \\
\hline Kp. Penambang & 3 & 18 \\
Rendah & 1 & 6 \\
Sedang & 13 & 76 \\
Tinggi & 18 & 100 \\
\hline Total & & \\
\hline Kp. Bunga & 5 & 36 \\
Rendah & 2 & 14 \\
Sedang & 6 & 43 \\
Tinggi & 14 & 100 \\
\hline Total & & \\
\hline Kp. Susu & 5 & 42 \\
Rendah & 1 & 8 \\
Sedang & 6 & 50 \\
Tinggi & 12 & 100 \\
\hline Total & & \\
\hline
\end{tabular}

Berdasarkan Tabel 4 tingkat norma masyarakat pada setiap kampung termasuk ke dalam kategori tinggi. Pada Kampung Bunga, tingginya norma yang diberlakukan terjadi karena sejak awal penetapannya, masyarakat yang menjadi petani bunga menyetujui dilaksanakannya peraturan menyeragamkan harga jual. Penanaman bunga yang dilakukan oleh masyarakat di Kampung Bunga dilakukan secara bersamaan sehingga bunga yang 
dijual memiliki jenis dan ukuran yang hampir sama. Selain itu, jika salah satu masyarakat mendapatkan pesanan bunga yang cukup banyak, jumlah bunga yang dibutuhkan akan dibagi rata ke setiap petani bunga sehingga keunntungan yang didapatkan dapat terbagi sama rata.

\section{Jaringan Sosial}

Jaringan merupakan hal yang sangat diperlukan oleh seseorang dalam menjalani kehidupan sosial. Jaringan yang dimiliki seseorang akan memberikan dampak bagi orang itu sendiri maupun orang lain. Jaringan merupakan relasi yang dimiliki oleh seseorang dengan orang lain. Kunci keberhasilan dari membangun modal sosial terletak pada kemampuan orang melibatkan diri dalam suatu jaringan hubungan sosial. Tingginya jaringan sosial yang dimiliki oleh seseorang dapat digambarkan dengan seberapa dekat seseorang dengan jaringanjaringan yang dimilikinya dan bagaimana jaringan tersebut dapat membantu aktivitas sehari-hari yang dilakukan oleh masyarakat yang bersangkutan tersebut (Wicaksono 2016). Jaringan sosial akan memberikan manfaat bagi para pelakunya. salah satunya dengan memelihara hubungan baik terhadap stakeholder-stakeholder atau pihak-pihak terkait. Jumlah dan persentase tingkat jaringan masyarakat berdasarkan brand kampung Desa Tamansari disajikan pada Tabel 5.

Tabel 5 Jumlah dan persentase tingkat jaringan masyarakat berdasarkan brand Kampung wisata Desa Tamansari tahun 2017

\begin{tabular}{lcc}
\hline \multicolumn{1}{c}{ Jaringan } & Jumlah $(\mathrm{n})$ & Persentase (\%) \\
\hline Kp. Penambang & & \\
Rendah & 1 & 6 \\
Sedang & 3 & 18 \\
Tinggi & 13 & 76 \\
\hline Total & 17 & 100 \\
\hline Kp. Bunga & & \\
Rendah & 7 & 50 \\
Sedang & 4 & 29 \\
Tinggi & 3 & 21 \\
\hline Total & 14 & 100 \\
\hline Kp. Susu & & \\
Rendah & 4 & 33 \\
Sedang & 3 & 25 \\
Tinggi & 5 & 42 \\
\hline Total & 12 & 100 \\
\hline
\end{tabular}

Tabel 5 menunjukkan bahwa tingkat jaringan masyarakat Desa Tamansari yang paling tinggi berada pada masyarakat di Kampung Penambang.
Hal tersebut dikarenakan selain menjadi penambang belerang, masyarakat di Kampung Penambang bekerja sebagai guide ataupun penyewa masker, sehingga mereka lebih sering berinteraksi dengan pengujung ataupun pihak lainnya dibandingkan dengan masyarakat di kampung lain. Selain itu, kemampuan berkomunikasi yang dimiliki oleh masyarakat di Kampung Penambang melebihi masyarakat lainnya, sehingga jaringan yang mereka dapatkan berasal dari para pengunjung yang menyewa jasa mereka sebagai guide ataupun penyewa masker. Selain itu jaringan yang diperoleh terlihat dari semakin banyaknya pengunjung ataupun pihak-pihak lain yang datang dan turut membantu Desa Tamansari menjadi lebih berkembang. Selama setahun terakhir sebanyak 186.000 pengunjung tercatat mengunjungi Kawah Ijen dan melewati Desa Tamansari.

\section{Faktor Pendorong Partisipasi}

Faktor pendorong partisipasi merupakan hal yang dibutuhkan oleh setiap individu untuk memotivasi diri mereka sendiri agar dapat ikutserta dalam suatu kegiatan. Partisipasi masyarakat dalam proses suatu pembangunan dapat terwujud nyata jika faktorfaktor yang mendukungnya terpenuhi. Pembahasan faktor pendorong partisipasi dalam penelitian ini difokuskan pada ketiga unsur tersebut di mana ketiga unsur tersebut menjadi faktor-faktor yang dapat meningkatkan ataupun menghambat individu untuk berpartisipasi. Penelitian ini menjelaskan hasil identifikasi unsur-unsur faktor pendorong partisipasi meliputi kemauan, kemampuan, dan kesempatan yang diterapkan oleh masyarakat Desa Tamansari dan untuk mengetahui peran faktor pendorong partisipasi yang dimiliki oleh masyarakat di setiap brand Kampung Wisata Tamansari dalam mendukung berjalannya pembangunan desa wisata di Desa Tamansari sehingga menjadi salah satu desa binaan yang dijadikan percontohan oleh desa lainnya. Jumlah dan persentase tingkat faktor pendorong partisipasi responden berdasarkan brand kampung diuraikan pada Tabel 6 .

Tabel 6 menunjukkan bahwa faktor pendorong partisipasi yang dimiliki oleh masyarakat di setiap kampung berada pada kategori tinggi. Hasil persentase faktor pendorong partisipasi yang paling tinggi berada pada Kampung Penambang yaitu sebesar 88 persen. Hal tersebut dikarenakan mayoritas masyarakat di Kampung Penambang sudah merasakan manfaat dari dijadikannya Desa 
Tamansari sebagai desa wisata. Selain itu, mayoritas masyarakat di Kampung Penambang selalu menyempatkan waktu yang mereka miliki untuk turut serta dalam kegiatan desa. Sama halnya seperti Kampung Penambang, tingkat faktor pendorong partisipasi yang dimiliki oleh masyarakat Kampung Bunga dan Kampung Susu juga berada pada kategori tinggi.

Tabel 6 Jumlah dan persentase tingkat faktor pendorong partisipasi responden berdasarkan brand Kampung Wisata Tamansari tahun 2017

\begin{tabular}{lcc}
\hline $\begin{array}{l}\text { Faktor Pendorong } \\
\text { Partisipasi }\end{array}$ & Jumlah (n) & Persentase (\%) \\
\hline Kp Penambang & & \\
Rendah & 0 & 0 \\
Sedang & 2 & 12 \\
Tinggi & 15 & 88 \\
\hline Total & 43 & 100 \\
\hline Kp Bunga & & \\
Rendah & 0 & 0 \\
Sedang & 4 & 29 \\
Tinggi & 10 & 71 \\
\hline Total & 43 & 100 \\
\hline Kp Susu & & \\
Rendah & 1 & 8 \\
Sedang & 1 & 8 \\
Tinggi & 10 & 83 \\
\hline Total & 43 & 100 \\
\hline
\end{tabular}

\section{Kemauan}

Kemauan merupakan suatu dorongan yang dapat menumbuhkan minat serta sikap individu agar termotivasi untuk berpartisipasi. Menurut Lugiarti (2004) kemauan individu ditentukan oleh faktor yang bersifat psikologis, seperti motiv, harapan, kebutuhan, dan imbalan. Lugiarti (2004) menjelaskan, bahwa dorongan individu melakukan suatu kegiatan tergantung pada seberapa besar harapannya untuk mencapai suatu tujuan. Harapan mendapatkan imbalan atau manfaat tertentu merupakan sumber motivasi individu untuk dapat berpartisipasi dalam setiap kegiatan pembangunan.

Tabel 7 menunjukkan bahwa masyarakat Desa Tamansari memiliki kemauan berupa harapan yang besar terhadap kemajuan pembangunan Desa Tamansari sebagai salah satu desa wisata di Kabupaten Banyuwangi. Kemauan masyarakat yang paling tinggi terdapat pada masyarakat Kampung Penambang yaitu sebesar 94 persen. Hal tersebut terbukti dari kehadiran masyarakat pada setiap rapat yang diselenggarakan, kerja bakti yang diadakan, dan kegiatan lainnya. Masyarakat Kampung Penambang selalu memiliki kemauan untuk lebih memajukan kawasan Kampung Penambang, dikarenakan Kampung Penambang masih jauh tertinggal dibandingkan kampung lainnya.

Tabel 7 Jumlah dan persentase tingkat kemauan masyarakat berdasarkan brand kampung wisata Desa Tamansari tahun 2017

\begin{tabular}{lcc}
\hline \multicolumn{1}{c}{ Kemauan } & Jumlah (n) & Persentase (\%) \\
\hline Kp. Penambang & & \\
Rendah & 0 & 0 \\
Sedang & 1 & 6 \\
Tinggi & 16 & 94 \\
\hline Total & 17 & 100 \\
\hline Kp. Bunga & & \\
Rendah & 2 & 14 \\
Sedang & 3 & 21 \\
Tinggi & 9 & 64 \\
\hline Total & 14 & 100 \\
\hline Kp. Susu & & \\
Rendah & 1 & 8 \\
Sedang & 2 & 17 \\
Tinggi & 9 & 75 \\
\hline Total & 12 & 100 \\
\hline
\end{tabular}

\section{Kesempatan}

Kesempatan merupakan suatu suasana atau kondisi lingkungan yang disadari bahwa individu tersebut memiliki peluang untuk berpartisipasi (Lugiarti 2004). Pada umumnya, setiap individu pasti memiliki kesempatan untuk dapat berpartisipasi, tetapi dalam beberapa hal individu tidak mendapatkan kesempatan yang sama dikarenakan adanya perbedaan di setiap individu. Meskipun setiap kampung wisata memiliki perbedaan wisata yang ditawarkan, namun ketiga brand kampung tersebut tetap menjadi satu kesatuan dalam Kampung Wisata Tamansari. Jumlah dan persentase tingkat kesempatan masyarakat berdasarkan brand kampung di Desa Tamansari diuraikan pada Tabel 8.

Tabel 8 menunjukkan bahwa kesempatan yang diberikan kepada masyarakat pada masing-masing kampung tidak sama. Tingkat kesempatan pada masyarakat Kampung Bunga terletak pada kategori tinggi yaitu sebesar 57 persen. Hal tersebut dikarenakan hampir semua responden mendapatkan kesempatan diundang dalam setiap kegiatan desa. Tingkat kesempatan masyarakat dalam Kampung 
Penambang dan Kampung Susu berada pada kategori sedang. Hal tersebut dikarenakan letak dusun atau kampung tersebut jauh dari balai desa, sehingga tidak semua masyarakat memiliki kesempatan untuk diundang. Biasanya, masyarakat yang diundang dari Kampung Penambang dan Kampung Susu merupakan kepala dusun, RT, dan RW saja.

Tabel 8 Jumlah dan persentase tingkat kesempatan masyarakat berdasarkan brand kampung wisata Desa Tamansari tahun 2017

\begin{tabular}{lcc}
\hline \multicolumn{1}{c}{ Kemauan } & Jumlah (n) & Persentase (\%) \\
\hline Kp. Penambang & 2 & 12 \\
Rendah & 7 & 41 \\
Sedang & 2 & 12 \\
Tinggi & 17 & 100 \\
\hline Total & & \\
\hline Kp. Bunga & 0 & 0 \\
Rendah & 6 & 43 \\
Sedang & 8 & 57 \\
Tinggi & 14 & 100 \\
\hline Total & & \\
\hline Kp. Susu & 0 & 0 \\
Rendah & 8 & 67 \\
Sedang & 4 & 33 \\
Tinggi & 12 & 100 \\
\hline Total & &
\end{tabular}

\section{Kemampuan}

Kemampuan merupakan suatu kesadaran atau keyakinan pada dirinya memiliki kemampuan untuk berpartisipasi melalui pikiran, tenaga, waktu, ataupun sarana material lainnya (Lugiarti 2004). Kemampuan individu dapat terlihat dari seberapa mampu masyarakat menghadiri rapat, seberapa mampu masyarakat mengikuti kegiatan desa, seberapa mampu masyarakat menyumbang kegiatan desa, dan seberapa mampu masyarakat mengikuti pelatihan-pelatihan yang dicanangkan. Tingkat kemampuan masyarakat Desa Tamansari tergolong ke dalam kategori tinggi karena masyarakat di Desa Tamansari memiliki tujuan yang ingin dicapai bersama-sama sehingga mereka akan mengusahakan hal-hal yang dapat meningkatkan pembangunan Desa Tamansari sebagai desa wisata. Jumlah dan persentase tingkat kemampuan masyarakat berdasarkan brand kampung wisata disajikan pada Tabel 9.
Tabel 9 Jumlah dan persentase tingkat kemampuan masyarakat berdasarkan brand kampung wisata Desa Tamansari tahun 2017

\begin{tabular}{lcc}
\hline Kemampuan & Jumlah (n) & Persentase (\%) \\
\hline Kp. Penambang & 2 & 12 \\
Rendah & 7 & 41 \\
Sedang & 2 & 12 \\
Tinggi & 17 & 100 \\
\hline Total & & \\
\hline Kp. Bunga & 0 & 0 \\
Rendah & 6 & 43 \\
Sedang & 8 & 57 \\
Tinggi & 14 & 100 \\
\hline Total & & \\
\hline Kp. Susu & 0 & 0 \\
Rendah & 8 & 67 \\
Sedang & 4 & 33 \\
Tinggi & 12 & 100 \\
\hline Total & & \\
\hline
\end{tabular}

Hubungan Karakteristik Individu dengan Modal Sosial dan Faktor Pendorong Partisipasi Masyarakat Desa Tamansari

ini akan mengidentifikasi dan mengkaji bagaimana hubungan antara karakteristik individu dengan modal sosial dan masyarakat tingkat faktor pendorong partisipasi. Modal sosial dan faktorfaktor pendorong partisipasi di dalam suatu masyarakat memiliki hubungan dengan karakteristik individu atau masyarakat itu sendiri. Bagaimana dia dapat dipercayai dan mempercayai, mentaati norma, serta seberapa banyak jaringan yang masyarakat miliki tergantung pada karakteristik dirinya sendiri, begitupun dengan bagaimana dia memiliki kemauan, kesempatan, dan kemampuan untuk dapat hadir dalam kegiatan-kegiatan yang dilaksanakan berhubungan dengan karakteristik masyarakat itu sendiri.

Tabel 10 Hasil nilai signifikansi usia, lama tinggal, tingkat pendidikan dengan tingkat modal sosial dan tingkat faktor pendorong partisipasi di Desa Tamansari tahun 2017

\begin{tabular}{lcc}
\hline $\begin{array}{c}\text { Karakteristik } \\
\text { Individu }\end{array}$ & $\begin{array}{c}\text { Tingkat } \\
\text { Modal Sosial }\end{array}$ & $\begin{array}{c}\text { Tingkat Faktor } \\
\text { Pendorong } \\
\text { Partisipasi }\end{array}$ \\
\hline Usia & 0.173 & 0.127 \\
Lama Tinggal & 0.100 & 0.046 \\
Tingkat & 0.105 & 0.051 \\
Pendidikan & & \\
\hline Keterangan : & ${ }^{* *}$ Correlation is significant at the 0.01 level (2-tailed) \\
& ${ }^{*}$ Correlation is significant at the 0.05 level (2-tailed)
\end{tabular}


Berdasarkan Tabel 10, karakteristik individu pada masyarakat Desa Tamansari memiliki hubungan yang tidak signifikan dengan modal sosial masyarakat ataupun dengan faktor pendorong partisipasi yang dimiliki oleh masyarakat. Jumlah dan persentase hubungan berdasarkan karakteristik individu responden dengan tingkat modal social dan faktor pendorong partisipasi responden pada masyarakat Desa Tamansari akan diuraikan pada Tabel 11.
Berdasarkan Tabel 11, tingkat modal sosial yang dimiliki oleh responden termasuk ke dalam kategori pada usia kategori menengah yaitu 39 tahun-50 tahun tahun $(72.7 \%)$. Hal tersebut terjadi karena masyarakat pada usia tersebut membutuhkan relasi dan juga lebih dapat meluangkan waktunya. Mayoritas responden usia tersebut belum menikah dan belum memiliki tanggungan ataupun curahan waktu untuk keluarga (anak dan istri) sehingga waktu yang tersedia dapat digunakan untuk berkumpul bersama masyarakat lainnya.

Tabel 11 Jumlah dan persentase hubungan berdasarkan karakteristik individu responden dengan tingkat modal sosial responden pada masyarakat Desa Tamansari tahun 2017

\begin{tabular}{|c|c|c|c|c|c|c|c|c|c|}
\hline \multicolumn{2}{|c|}{ Karakterisitik Individu } & \multicolumn{8}{|c|}{ Tingkat Modal Sosial } \\
\hline & & \multicolumn{2}{|c|}{ Rendah } & \multicolumn{2}{|c|}{ Sedang } & \multicolumn{2}{|c|}{ Tinggi } & \multicolumn{2}{|c|}{ Total } \\
\hline & & $\mathrm{n}$ & $\%$ & $\mathrm{n}$ & $\%$ & $\mathrm{n}$ & $\%$ & $\mathrm{n}$ & $\%$ \\
\hline \multirow[t]{4}{*}{ Usia } & Muda & 2 & 18.2 & 1 & 9.1 & 8 & 72.7 & 11 & 100.0 \\
\hline & Menengah & 2 & 7.1 & 11 & 39.3 & 15 & 53.6 & 28 & 100.0 \\
\hline & Tua & 0 & 0.0 & 3 & 75.0 & 1 & 25.0 & 4 & 100.0 \\
\hline & Total & 4 & 15 & 15 & 34 & 24 & 55.8 & 43 & 100.0 \\
\hline Tingkat & Rendah & 1 & 4.5 & 8 & 36.4 & 13 & 59.1 & 22 & 100.0 \\
\hline \multirow[t]{3}{*}{ Pendidikan } & Sedang & 2 & 13.3 & 5 & 33.3 & 8 & 53.3 & 15 & 100.0 \\
\hline & Tinggi & 1 & 16.7 & 2 & 33.3 & 3 & 50.0 & 6 & 100.0 \\
\hline & Total & 4 & 9.3 & 15 & 34.9 & 24 & 55.8 & 43 & 100.0 \\
\hline \multirow[t]{4}{*}{ Lama Tinggal } & Rendah & 2 & 14.3 & 5 & 35.7 & 7 & 50.0 & 14 & 100.0 \\
\hline & Sedang & 1 & 4.0 & 8 & 32.0 & 16 & 64.0 & 23 & 100.0 \\
\hline & Tinggi & 1 & 25.0 & 2 & 50.0 & 1 & 25.0 & 6 & 100.0 \\
\hline & Total & 4 & 9.3 & 15 & 34.9 & 24 & 55.8 & 43 & 100.0 \\
\hline
\end{tabular}

Tabel 11 juga menunjukkan bahwa tidak terdapat kecenderungan semakin tinggi atau semakin tua usia seseorang, semakin tinggi modal sosial yang dimiliki. Setelah diuji menggunakan uji korelasi Rank Spearman, didapatkan hasil $\alpha$ untuk hubungan antara usia responden dengan modal sosial reponden pada masyarakat Desa Tamansari adalah 0.266. hasil tersebut menunjukkan bahwa hubungan antar dua variabel tersebut tidak signifikan, karena nilai $\alpha$ lebih bedar dari 0.05 . Selain itu nilai korelasi yang didapatkan adalah sebesar 0.173. nilai tersebut menunjukkan bahwa hubungan antar dua variabel tersebut adalah sangat lemah. Hasil yang bernilai negatif memiliki arti hipotesis ditolak di mana hubungan yang terjadi antar kedua variabel tidak sejalan atau berlawanan. Hasil uji korelasi tersebut didukung oleh pernyataan responden sebagai berikut:

“...Yah di sini semua masyarakatnya
deket Mbak. Semua saling kenal kalau
di sini. Mau orang tua atau anak
muda semua pasti kenal. Malah kalau yang orang Madura itu kalau dia sudah punya anak, namanya diganti jadi nama anaknya. Kaya saya ini Mbak..." (SLT, 37 Tahun)

Berdasarkan Tabel 12, usia responden memiliki hubungan yang tidak signifikan terhadap modal sosial yang dimiliki oleh responden. Berdasarkan hasil tersebut, dapat dilihat bahwa sebanyak 90.0 persen responden memiliki faktor pendorong partisipasi yang tinggi dengan kategori usia rendah. Hasil uji korelasi Rank Spearman menunjukkan bahwa hubungan antar dua variabel tersebut tidak signifikan, karena nilai $\alpha$ lebih besar dari 0.05 . Selain itu, nilai korelasi yang didapatkan adalah sebesar 0.127. nilai tersebut menunjukkan bahwa hubungan antar dua variabel tersebut adalah sangat lemah. Hasil yang bernilai negatif memiliki arti bahwa hubungan antar variabel adalah berlawanan di mana semakin mudanya usia seseorang makan semakin tinggi faktor pendorong partisipasi yang dimiliki Hasil uji korelasi tersebut didukung oleh pernyataan responden sebagai berikut: 
“...Yah di sini tua muda semua ikut kerja bakti, semua dapat kesempatan yang sama. Biasanya kalau ibu-ibu siapin makanan kala ada kerja bakti gitu, bapaknya dan anak-anak muda biasanya yang sapusapu jalan. Kalau ronda gitupun pasti yang lebih semangat yang muda Mbak. Ne udah tua ya masuk angin toh..." (SNT, 44 Tahun)

Tabel 12 Jumlah dan persentase hubungan berdasarkan karakteristik individu responden dengan tingkat modal sosial responden pada masyarakat Desa Tamansari tahun 2017

\begin{tabular}{|c|c|c|c|c|c|c|c|c|c|}
\hline \multicolumn{2}{|c|}{ Karakterisitik Individu } & \multicolumn{8}{|c|}{ Tingkat Faktor Pendorong Partisipasi } \\
\hline & & \multirow{2}{*}{\multicolumn{2}{|c|}{$\begin{array}{r}\text { Rendah } \\
\%\end{array}$}} & \multicolumn{2}{|c|}{ Sedang } & \multicolumn{2}{|c|}{ Tinggi } & \multicolumn{2}{|c|}{ Total } \\
\hline & & & $\%$ & $\mathrm{n}$ & $\%$ & $\mathrm{n}$ & $\%$ & $\mathrm{n}$ & $\%$ \\
\hline \multirow[t]{4}{*}{ Usia } & Muda & 0 & 0.0 & 1 & 9.1 & 10 & 90.9 & 11 & 100.0 \\
\hline & Me-nengah & 1 & 3.5 & 4 & 14.3 & 23 & 82.1 & 28 & 100.0 \\
\hline & Tua & 0 & 0.0 & 1 & 25.0 & 3 & 75.0 & 4 & 100.0 \\
\hline & Total & 4 & 15 & 15 & 34 & 24 & 55.8 & 43 & 100.0 \\
\hline \multirow{4}{*}{$\begin{array}{l}\text { Tingkat Pen- } \\
\text { didikan }\end{array}$} & Rendah & 1 & 4.5 & 2 & 9.1 & 19 & 86.4 & 22 & 100.0 \\
\hline & Sedang & 0 & 0.0 & 3 & 20.0 & 12 & 80.0 & 15 & 100.0 \\
\hline & Tinggi & 0 & 0.0 & 1 & 16.7 & 5 & 83.3 & 6 & 100.0 \\
\hline & Total & 1 & 2.3 & 5 & 14 & 36 & 83.7 & 43 & 100.0 \\
\hline \multirow[t]{4}{*}{ Lama Tinggal } & Rendah & 1 & 7.1 & 1 & 7.1 & 12 & 85.7 & 14 & 100.0 \\
\hline & Sedang & 0 & 0.0 & 4 & 16.0 & 21 & 84.0 & 25 & 100.0 \\
\hline & Tinggi & 0 & 0.0 & 1 & 25.0 & 3 & 75.0 & 4 & 100.0 \\
\hline & Total & 1 & 9.3 & 6 & 34.9 & 35 & 55.8 & 43 & 100.0 \\
\hline
\end{tabular}

Hasil tersebut menunjukkan bahwa adanya hubungan yang tidak signifikan antara faktor pendorong partisipasi dengan tingkat pendidikan yang dimiliki oleh responden. Selain itu, hubungan tidak signifikan juga terjadi antara lama tinggal responden dengan faktor pendorong partisipasi responden, di mana faktor pendorong partisipasi responden terletak pada kategori tinggi dengan lama tinggal responden rendah. Berdasarkan keadaan lapang, faktor pendorong partisipasi yang dimiliki oleh masyarakat Desa Tamansari sudah tinggi sehingga, rendah, sedang, atau tingginya lama responden menetap di desa tidak berhubungan dengan faktor pendorong partisipasi masyarakat di Desa Tamansari.

\section{Partisipasi Masyarakat}

Partisipasi dapat juga diartikan sebagai suatu proses aktif dan inisiatif yang diambil dan dibimbing oleh cara berfikir mereka sendiri, dengan menggunakan sarana dan proses melalui lembaga dan mekanisme di mana mereka dapat menegaskan kontrol secara efektif (Nasdian 2014). Partisipasi pada program pembangunan sendiri diterapkan agar program dapat berjalan sesuai tujuan dan keinginan masyarakat. Berdasarkan teori diatas, pembangunan Desa Tamansari menjadi desa wisata dapat terlaksana dengan baik jika partisipasi masyarakat tumbuh dari inisiatif masyarakat itu sendiri.
Tabel 13 Jumlah dan persentase tingkat partisipasi masyarakat berdasarkan brand kampung wisata Desa Tamansari tahun 2017

\begin{tabular}{lcc}
\hline Kemampuan & Jumlah (n) & Persentase (\%) \\
\hline Kp. Penambang & 1 & 6 \\
Rendah & 8 & 47 \\
Sedang & 8 & 47 \\
Tinggi & 17 & 100 \\
\hline Total & & \\
\hline Kp. Bunga & 4 & 20 \\
Rendah & 7 & 50 \\
Sedang & 3 & 21 \\
Tinggi & 14 & 100 \\
\hline Total & & \\
\hline Kp. Susu & 3 & 17 \\
Rendah & 9 & 75 \\
Sedang & 0 & 0 \\
Tinggi & 12 & 100 \\
\hline Total & & \\
\hline
\end{tabular}

Berdasarkan Tabel 13, tingkat partisipasi masyarakat pada setiap brand berada pada kategori berbeda. Hal tersebut dikarenakan adanya perbedaan hasil pada setiap tahapan partisipasi yang dilakukan oleh masyarakat Desa Tamansari.

\section{Tahap Perencanaan}

Tahap perencanaan merupakan keterlibatan masyarakat dalam kegiatan-kegiatan terkait 
perencanaan program Desa Tamansari sebagai desa wisata sesuai dengan potensi dan kebutuhan masyarakat Desa Tamansari.

Tabel 14 Jumlah dan persentase tingkat perencanaan masyarakat berdasarkan brand kampung wisata Desa Tamansari tahun 2017

\begin{tabular}{lcc}
\hline \multicolumn{1}{c}{ Perencanaan } & Jumlah (n) & Persentase (\%) \\
\hline Kp. Penambang & & \\
Rendah & 8 & 47 \\
Sedang & 8 & 67 \\
Tinggi & 1 & 100 \\
\hline Total & 17 & \\
\hline Kp. Bunga & & 57 \\
Rendah & 8 & 29 \\
Sedang & 4 & 14 \\
Tinggi & 2 & 100 \\
\hline Total & 14 & \\
\hline Kp. Susu & & 75 \\
Rendah & 9 & 25 \\
Sedang & 3 & 0 \\
Tinggi & 0 & 100 \\
\hline Total & 12 & \\
\hline
\end{tabular}

Berdasarkan Tabel 14, tingkat partisipasi dalam tahap perencanaan pada setiap kampung menunjukkan hasil yang berbeda. Tingkat partisipasi dalam tahap perencanaan pada masyarakat Kampung Penambang berada pada kategori rendah dan sedang. Masyarakat Kampung Penambang mayoritas ikut terlibat dalam tahapan perencanaan pembangunan desa wisata, jika dibandingkan dengan Kampung Susu dan Kampung Bunga. Tingkat partisipasi dalam tahhap perencanaan pada masyarakat Kampung Bunga dan Kampung Susu berada pada kategori rendah yaitu sebesar 57 persen dan 75 persen. Hal tersebut terjadi karena masyarakat kedua kampung tersebut tidak seluruhnya dilibatkan pada tahap perencanaan. Hal tersebut diperkuat oleh pernyataan responden sebagai berikut :

\section{“...kalau awal mulanya sekali saya ndak paham mbak soalnya memang tidak diundang..." (IN, 40 Tahun)}

Rendahnya tingkat pada tahap perencanaan pembangunan Desa Tamansari sebagai desa wisata juga terjadi karena perencanaan direncanakan secara top down, sehingga yang mengetahui terlebih dahulu adalah ketua-ketua dusun, ketua RW, ketua RT, serta pengurus desa. Mayoritas masyarakat mengatakan bahwa masyarakan terkadang hanya mendapatkan informasi hasil rapat dari ketua dusun saja.

\section{Tahap Pelaksanaan}

Tahap pelaksanaan merupakan implementasi dari perencanaan yang telah disepakati. Pelaksanaan dapat disebut juga sebagai inti dari suatu program pembangunan. Pelaksanaan merupakan hal yang penting dan harus melibatkan masyarakat karena seberapa tinggi dan baiknya suatu rencana yang telah dibuat jika tidak dilaksanakan atau diimplementasikan maka tidak diketahui bagaimana hasilnya. Tingkat partisipasi masyarakat pada tahap pelaksanaan merupakan cara untuk melihat sejauh mana keterlibatan masyarakat baik pada keikutsertaannya dalam kegiatan desa maupun pada pengelolaan kawasan desa.

Tabel 15 Jumlah dan persentase tingkat pelaksanaan masyarakat berdasarkan brand kampung wisata Desa Tamansari tahun 2017

\begin{tabular}{lcc}
\hline \multicolumn{1}{c}{ Pelaksanaan } & Jumlah (n) & Persentase (\%) \\
\hline Kp. Penambang & & \\
Rendah & 0 & 0 \\
Sedang & 2 & 12 \\
Tinggi & 15 & 88 \\
\hline Total & 17 & 100 \\
\hline Kp. Bunga & & \\
Rendah & 1 & 7 \\
Sedang & 8 & 57 \\
Tinggi & 5 & 36 \\
\hline Total & 14 & 100 \\
\hline Kp. Susu & & \\
Rendah & 0 & 0 \\
Sedang & 4 & 33 \\
Tinggi & 8 & 67 \\
\hline Total & 12 & 100 \\
\hline
\end{tabular}

Berdasarkan Tabel 15, tingkat partisipasi masyarakat dalam tahapan pelaksanaan dominan inggi pada masyarakat di Kampung Penambang dan Kampung Susu. Mayoritas masyarakat di Kampung Penambang dan Kampung Susu bermatapencaharian homogen, sehingga dalam pelaksanaaan pembangunan desa mereka menyempatkan untuk turut berpartisipasi, terutama pada masyarakat di Kampung Penambang. Pelaksanaan pembangunan desa wisata di Desa Tamansari mengundang banyak perhatian pemerintah maupun pengunjung sehingga semakin meningkatnya kunjungan ke Kawah Ijen serta meningkatnya jumlah pengunjung yang singgah di Desa Tamansari

\section{Tahap Pengawasan}

Tahap pengawasan merupakan tahap evaluasi atau peninjauan kembali bagaimana pembangunan desa 
wisata di Desa Tamansari untuk dilihat apakah pelaksanaannya yang sudah berjalan, apakah sudah tepat dengan sasaran, apakah sesuai antara tujuan yang diharapkan dengan keadaan sekarang, dan bersama-sama mencari solusi apabila terdapat kendala-kendala yang menghambat jalannya pembangunan tersebut. Rapat tahap evaluasi pada pembangunan desa wisata di Desa Tamansari ini baru diadakan sebanyak dua kali. Hal tersebut dilakukan untuk mengevaluasi kegiatan-kegiatan yang sudah berjalan.

Keterlibatan setiap pihak seperti masyarakat, pemerintah desa, pihak BCA, dan pihak-pihak lainnya sangat dibutuhkan dalam tahapan ini agar mampu bersama-sama mencari dan membari masukan untuk memperbaiki hal-hal yang menjadi kendala.

Tabel 16 Jumlah dan persentase tingkat pengawasan masyarakat berdasarkan brand kampung wisata Desa Tamansari tahun 2017

\begin{tabular}{lcc}
\hline \multicolumn{1}{c}{ Pengawasan } & Jumlah (n) & Persentase (\%) \\
\hline Kp. Penambang & 4 & \\
Rendah & 9 & 24 \\
Sedang & 4 & 53 \\
Tinggi & 17 & 100 \\
\hline Total & & \\
\hline Kp. Bunga & 94 \\
Rendah & 4 & 29 \\
Sedang & 1 & 7 \\
Tinggi & 14 & 100 \\
\hline Total & & \\
\hline Kp. Susu & 11 & 92 \\
Rendah & 1 & 8 \\
Sedang & 0 & 0 \\
Tinggi & 12 & 100 \\
\hline Total & & \\
\hline
\end{tabular}

Tabel 16 menunjukkan bahwa tingkat partisipasi masyarakat dalam tahap pengawasan pada setiap kampung menunjukkan hasil yang berbeda. Pada Kampung Penambang, tahapan pengawasan berada pada kategori sedang. Hal tersebut dikarenakan mayoritas masyarakat Kampung Penambang memiliki intensitas bertemu dengan pengunjung yang lebih sering, sehingga memungkinkan mereka untuk melakukan pengwasan, sedangkan Kampung Bunga dan Kampung Susu menunjukkan tahapan pengawasan berada pada kategori rendah. Hal tersebut dikarenakan kedua kampung tersebut belum banyak dikunjungi oleh pengunjung, sehingga peranan masyarakat dalam tahap pengawasan belum terlalu diperlukan.

\section{Hubungan Partisipasi dengan Tingkat Modal Sosial dan Faktor Pendorong Partisipasi Masyarakat Desa Tamansari}

Modal sosial dalam suatu masyarakat dan partisipasi dalam suatu masyarakat merupakan kedua konsep yang berbeda namun saling berhubungan dalam kehidupan bermasyarakat. Modal sosial merupakan wujud nilai dan norma informal yang dimiliki bersama kelompok masyarakat mampu menumbuhkan kerjasama di dalam masyarakat (Alfitri 2011). faktor pendorong partisipasi adalah faktor-faktor yang dapat memotivasi seseorang untuk dapat ikut serta dalam kegiatan pembangunan. Pendugaan bahwa adanya hubungan antara tingkat modal sosial dan tingkat faktor pendorong partisipasi terhadap partisipasi masyarakat dalam upaya pembangunan desa wisata di Desa Tamansari diuji menggunakan uji statistik korelasi non-parametrik Rank Spearman

Tabel 17 Hasil nilai signifikansi tahap perencanaan, tahap pelaksanaan, dan tahap evaluasi/ pengawasan dengan tingkat modal sosial dan tingkat faktor pendorongpartisipasi di Desa Tamansari tahun 2017

\begin{tabular}{lcc}
\hline $\begin{array}{c}\text { Partisipasi } \\
\text { Masyarakat }\end{array}$ & $\begin{array}{c}\text { Tingkat Modal } \\
\text { Sosial }\end{array}$ & $\begin{array}{c}\text { Tingkat Faktor } \\
\text { Pendorong } \\
\text { Partisipasi }\end{array}$ \\
\hline $\begin{array}{l}\text { Tahap } \\
\text { Perencanaan } \\
\text { Tahap }\end{array}$ & 0.136 & 0.139 \\
$\begin{array}{l}\text { Pelaksanaan } \\
\text { Tahap }\end{array}$ & $0.378 *$ & 0.180 \\
Pengawasan & $0.355^{*}$ & 0.167 \\
\hline $\begin{array}{l}\text { Keterangan **Correlation is significant at the } 0.01 \text { level (2-tailed) } \\
:\end{array}$ & $*$ Correlation is significant at the 0.05 level (2-tailed)
\end{tabular}

Tanda bintang $(*)$ pada koefisien korelasi menunjukkan adanya signifikasi hubungan antara variabel-variabel yang diuji. Semakin tingginya signifikasi atau hubungan yang terjadi di antara varibel-variabel yang diuji tersebut, dapat dilihat dari semakin banyaknya tanda bintang (*). Variabel yang memiliki hubungan yang signifikan daat dilihat dari nilai Sig.(2-sided) atau $p$-value lebih kecil dari taraf nyata yaitu $\alpha=0,05$.

\section{Hubungan Partisipasi Masyarakat dengan Tingkat Modal Sosial}

Modal sosial dan partisipasi merupakan dua konsep yeng berbeda namun memiliki keterhubungan. Modal sosial akan memberikan manfaat terhadap bertambah baiknya interaksi di dalam suatu 
masyarakat begitupun dengan partisipasi di dalam suatu masyarakat. Keduanya merupakan kompone yang dibutuhkan oleh masyarakat dalam menjalankan kehidupan bermasyarakat. Berdasarkan uji korelasi Rank Spearman, partisipasi masyarakat memiliki hubungan signifikan dengan tingkat modal sosial pada tahapan pelaksanaan dan tahap penkawasan atau evaluasi. Jumlah dan persentase hubungan antara kedua variabel tersebut dapat dilihat dalam Tabel 18.

Tabel 18 Jumlah dan persentase hubungan berdasarkan partisipasi masyarakat dengan tingkat modal sosial dalam masyarakat di Desa Tamansari tahun 2016

\begin{tabular}{|c|c|c|c|c|c|c|c|c|c|}
\hline \multicolumn{2}{|c|}{ Karakterisitik Individu } & \multicolumn{8}{|c|}{ Tingkat Faktor Pendorong Partisipasi } \\
\hline & & \multicolumn{2}{|c|}{ Rendah } & \multicolumn{2}{|c|}{ Sedang } & \multicolumn{2}{|c|}{ Tinggi } & \multicolumn{2}{|c|}{ Total } \\
\hline & & $\mathrm{n}$ & $\%$ & $\mathrm{n}$ & $\%$ & $\mathrm{n}$ & $\%$ & $\mathrm{n}$ & $\%$ \\
\hline \multirow[t]{4}{*}{ Tahap Perencanaan } & Rendah & 0 & 0.0 & 1 & 9.1 & 10 & 90.9 & 11 & 100.0 \\
\hline & Sedang & 1 & 3.5 & 4 & 14.3 & 23 & 82.1 & 28 & 100.0 \\
\hline & Tinggi & 0 & 0.0 & 1 & 25.0 & 3 & 75.0 & 4 & 100.0 \\
\hline & Total & 4 & 15 & 15 & 34 & 24 & 55.8 & 43 & 100.0 \\
\hline \multirow[t]{4}{*}{ Tahap Pelaksanaan } & Rendah & 1 & 4.5 & 2 & 9.1 & 19 & 86.4 & 22 & 100.0 \\
\hline & Sedang & 0 & 0.0 & 3 & 20.0 & 12 & 80.0 & 15 & 100.0 \\
\hline & Tinggi & 0 & 0.0 & 1 & 16.7 & 5 & 83.3 & 6 & 100.0 \\
\hline & Total & 1 & 2.3 & 5 & 14 & 36 & 83.7 & 43 & 100.0 \\
\hline \multirow[t]{4}{*}{ Tahap Pengawasan } & Rendah & 1 & 7.1 & 1 & 7.1 & 12 & 85.7 & 14 & 100.0 \\
\hline & Sedang & 0 & 0.0 & 4 & 16.0 & 21 & 84.0 & 25 & 100.0 \\
\hline & Tinggi & 0 & 0.0 & 1 & 25.0 & 3 & 75.0 & 4 & 100.0 \\
\hline & Total & 1 & 9.3 & 6 & 34.9 & 35 & 55.8 & 43 & 100.0 \\
\hline
\end{tabular}

Tahap perencanaan pada partisipasi responden memiliki hubungan yang tidak signifikan terhadap modal sosial yang dimiliki oleh responden. Berdasarkan hasil dari Tabel 48, dapat dilihat bahwa sebanyak 75.0 persen responden memiliki modal sosial yang sedang serta keikutsertaanya dalam tahap perencanaan termasuk ke dalam kategori sedang. Hasil uji korelasi Rank Spearman menunjukkan bahwa hubungan antar dua variabel tersebut tidak signifikan yaitu sebesar 0.386 , nilai korelasi yang didapatkan adalah sebesar 0.136. nilai tersebut menunjukkan bahwa hubungan antar dua variabel tersebut adalah sangat lemah.

Berdasarkan Tabel 18, tahap pelaksanaan pada partisipasi memiliki hubungan yang signifikan terhadap modal sosial masyarakat. Hasil uji korelasi Rank Spearman menunjukkan bahwa hubungan antar dua variabel tersebut signifikan yaitu sebesar 0.012 , karena nilai $\alpha$ lebih kecil dari 0.05 . Nilai korelasi yang didapatkan adalah sebesar 0378 yang berarti hubungan korelasi adalah cukup. Tahap pengawasan atau evaluasi pada partisipasi masyarakat memiliki hubungan yang signifikan dengan modal sosial yang dimiliki oleh masyarakat. Hasil uji korelasi Rank Spearman yang menunjukkan bahwa hubungan antar dua variabel tersebut signifikan yaitu sebesar 0.02 , karena nilai $\alpha$ lebih kecil dari 0.05 , dengan nilai korelasi yang didapatkan adalah sebesar 0.355 yang berarti hubungan korelasi adalan cukup. Hasil yang bernilai positif memiliki arti bahwa hubungan antar variabel adalah searah di mana semakin tingginya keikutsertaan seseorang dalam berpartisipasi maka semakin tinggi modal sosial yang dimiliki.

\section{Hubungan Partisipasi dengan Tingkat Faktor Pendorong Partisipasi}

Faktor pendorong masyarakat dengan partisipasi merupakan konsep berbeda. Faktor pendorong partisipasi individu akan memberikan motivasi yang berbeda-beda sehingga dalam setiap individu memiliki derajat keterlibatan yang berbeda juga.

Berdasarkan Tabel 19, tahap perencanaan, tahap pelaksanaan, maupun tahap pengawasan atau evaluasi pada partisipasi memiliki hubungan yang tidak signifikan terhadap faktor pendorong partisipasi masyarakat. Hal tersebut terjadi karena faktor pendorong yang dmiliki oleh masyarakat sudah tinggi, tetapi dalam pelaksanaan proses pembangunan tidak semua masyarakat medapatkan peluang untuk dapat menyumbangkan tenaga dan pikiran yang mereka miliki dikarenakan sistem informasi masih banyak yang bersifat top down di mana masyarakat hanya mendapatkan hasil dari diskusi yang telah dilakukan tanpa ikut terlibat dalam diskusi tersebut. 
Tabel 19 Jumlah dan persentase hubungan berdasarkan faktor pendorong partisipasi responden dengan partisipasi reponden pada masyarakat di Desa Tamansari tahun 2017

\begin{tabular}{|c|c|c|c|c|c|c|c|c|c|}
\hline \multicolumn{2}{|c|}{ Karakterisitik Individu } & \multicolumn{8}{|c|}{ Tingkat Faktor Pendorong Partisipasi } \\
\hline & & \multicolumn{2}{|c|}{ Rendah } & \multicolumn{2}{|c|}{ Sedang } & \multicolumn{2}{|c|}{ Tinggi } & \multicolumn{2}{|c|}{ Total } \\
\hline & & $\mathrm{n}$ & $\%$ & $\mathrm{n}$ & $\%$ & $\mathrm{n}$ & $\%$ & $\mathrm{n}$ & $\%$ \\
\hline Tahap & Rendah & 0 & 0.0 & 1 & 9.1 & 10 & 90.9 & 11 & 100.0 \\
\hline \multirow[t]{3}{*}{ Perencanaan } & Sedang & 1 & 3.5 & 4 & 14.3 & 23 & 82.1 & 28 & 100.0 \\
\hline & Tinggi & 0 & 0.0 & 1 & 25.0 & 3 & 75.0 & 4 & 100.0 \\
\hline & Total & 4 & 15 & 15 & 34 & 24 & 55.8 & 43 & 100.0 \\
\hline Tahap & Rendah & 1 & 4.5 & 2 & 9.1 & 19 & 86.4 & 22 & 100.0 \\
\hline \multirow[t]{3}{*}{ Pelaksanaan } & Sedang & 0 & 0.0 & 3 & 20.0 & 12 & 80.0 & 15 & 100.0 \\
\hline & Tinggi & 0 & 0.0 & 1 & 16.7 & 5 & 83.3 & 6 & 100.0 \\
\hline & Total & 1 & 2.3 & 5 & 14 & 36 & 83.7 & 43 & 100.0 \\
\hline Tahap & Rendah & 1 & 7.1 & 1 & 7.1 & 12 & 85.7 & 14 & 100.0 \\
\hline \multirow[t]{3}{*}{ Pengawasan } & Sedang & 0 & 0.0 & 4 & 16.0 & 21 & 84.0 & 25 & 100.0 \\
\hline & Tinggi & 0 & 0.0 & 1 & 25.0 & 3 & 75.0 & 4 & 100.0 \\
\hline & Total & 1 & 9.3 & 6 & 34.9 & 35 & 55.8 & 43 & 100.0 \\
\hline
\end{tabular}

\section{Pembangunan Desa Wisata}

Pembangunan merupakan upaya memperbaiki sesuatu hal menjadi lebih baik dan merupakan hal yang tidak bisa dihilangkan dalam rangka perbaikan suatu kondisi. Pembangunan desa wisata di Desa Tamansari merupakan salah satu upaya perbaikan kondisi masyarakat yang dapat dilakukan. Berdasarkan teori diatas, pembangunan Desa Tamansari menjadi desa wisata dapat terlaksana dengan baik jika masyarakat tumbuh dapat memperoleh manfaat dari adanya pembangunan desa wisata tersebut.

Tabel 20 Jumlah dan persentase responden berdasarkan tingkat pembangunandesa wisata pada brand kampung masyarakat Desa Tamansari tahun 2017

\begin{tabular}{lcc}
\hline \multicolumn{1}{c}{$\begin{array}{c}\text { Pembangunan } \\
\text { Desa }\end{array}$} & Jumlah (n) & Persentase (\%) \\
\hline Kp. Penambang & 2 & 12 \\
Rendah & 6 & 35 \\
Sedang & 9 & 53 \\
Tinggi & 17 & 100 \\
\hline Total & & \\
\hline Kp. Bunga & 9 & 64 \\
Rendah & 4 & 29 \\
Sedang & 1 & 7 \\
Tinggi & 14 & 100 \\
\hline Total & & \\
\hline Kp. Susu & 9 & 75 \\
Rendah & 2 & 17 \\
Sedang & 1 & 8 \\
Tinggi & 12 & 100 \\
\hline Total & & \\
\hline
\end{tabular}

Hasil dan manfaat yang diperoleh masyarakat yang berpartisipasi atas pembangunan desa wisata berbeda-beda pada setiap kampung. Mereka yang berpartisipasi dan memiliki lapangan pekerjaan yang semakin dekat dengan lokasi wisata cenderung lebih banyak memperoleh mafaat dari adanya pembangunan Desa Tamansari sebagai desa wisata ini. Peningkatan pembangunan di suatu desa tidak hanya dapat dilihat dari bagaimana pembangunan infrstrukturnya saja, melainkan dapat dilihat dari bagaimana peningkatan yang dirasakan oleh masyarakat desa itu sendiri.

\section{Kapasitas Diri}

Kapasitas diri merupakan suatu derajat kemampuan seseorang yang selalu dapat ditingkatkan. Keterlibatan masyarakat yang tinggi dalam setiap kegiatan yang diadakan menjadi faktor utama meningkatnya kapasitas diri mereka. Adanya pelatihan-pelatihan yang diselenggarakan meningkatkan keingintahuan mereka terhadap kawasan, meningkatkan kemampuan mereka dalam berkomunikasi, dan meningkatkan rasa peduli mereka terhadap kelestarian dan peningkatan mutu kawasan.

Berdasarkan Tabel 21, tingkat kapasitas diri yang dirasakan oleh masyarakat di setiap kampung adalah berbeda. Pada Kampung Penambang, tingkat kapasitas diri yang dirasakan oleh masyarakat termasuk ke dalam kategori tinggi, karena masyarakat Kampung Penambang selalu mengikuti pelatihan yang diadakan. Selain itu, masyarakat Kampung Penambang telah merasakan manfaat dari pembangunan desa wisata, sehingga mereka percaya 
bahwa Desa Tamansari akan berkembang jika dikelola dengan baik oleh masyarakat, sedangkab masyarakat Kampung Susu dan Kampung Bunga memiliki tingkat kapasitas diri yang lebih rendah. Penyebab dari hal tersebut karena masyarakat pada kampung tersebut hanya mengikuti kegiatan yang berhubungan dengan kebutuhan mereka, sehingga peningkatan kapasitas diri yang mereka rasakan tidak terlalu besar.

Tabel 21 Jumlah dan persentase tingkat kapasitas diri masyarakat berdasarkan brand kampung wisata Desa Tamansari tahun 2017

\begin{tabular}{lcc}
\hline \multicolumn{1}{c}{ Kapasitas Dir } & Jumlah (n) & Persentase (\%) \\
\hline Kp. Penambang & & \\
Rendah & 0 & 0 \\
Sedang & 2 & 12 \\
Tinggi & 15 & 88 \\
\hline Total & 17 & 100 \\
\hline Kp. Bunga & & \\
Rendah & 4 & 29 \\
Sedang & 9 & 64 \\
Tinggi & 1 & 7 \\
\hline Total & 14 & 100 \\
\hline Kp. Susu & & \\
Rendah & 7 & 58 \\
Sedang & 4 & 33 \\
Tinggi & 1 & 8 \\
\hline Total & 12 & 100 \\
\hline
\end{tabular}

\section{Tingkat Pendapatan}

Pendapatan merupakan jumlah uang yang didapatkan oleh seseorang untuk memenuhi kebutuhan hidupnya. Jumlah uang yang dimaksud adalah seberapa banyak penghasilan yang didapatkan dari adanya pembangunan desa wisata di Desa Tamansari.

Pendapatan masyarakat di Desa Tamansari menunjukkan hasil yang berbeda pada setiap individu di setiap brand kampung. Hal tersebut diuraikan pada Tabel 22.

Berdasarkan Tabel 22, tingkat pendapatan masyarakat pada masing-masing kampung berada pada kategori rendah, karena pembangunan Desa Tamansari sebagai desa wisata baru berjalan selama satu tahun terakhir, sehingga masih belum banyaknya pengunjung. Selain itu, masih banyaknya hal yang perlu diperbaiki dalam kawasan agar dapat menarik lebih banyak pengunjung yang datang ke Desa Tamansari dan pendapatan masyarakat akan lebih meningkat lagi.
Tabel 22 Jumlah dan persentase tingkat pendapatan masyarakat berdasarkan brand kampung wisata Desa Tamansari tahun 2017

\begin{tabular}{lcc}
\hline \multicolumn{1}{c}{ Pendapatan } & Jumlah (n) & Persentase (\%) \\
\hline Kp. Penambang & & \\
Rendah & 8 & 47 \\
Sedang & 4 & 24 \\
Tinggi & 5 & 29 \\
\hline Total & 17 & 100 \\
\hline Kp. Bunga & & \\
Rendah & 7 & 50 \\
Sedang & 6 & 43 \\
Tinggi & 1 & 7 \\
\hline Total & 14 & 100 \\
\hline Kp. Susu & & \\
Rendah & 7 & 58 \\
Sedang & 4 & 33 \\
Tinggi & 1 & 8 \\
\hline Total & 12 & 100 \\
\hline
\end{tabular}

\section{Hubungan Partisipasi dengan Tingkat Pembangunan Desa Wisata di Desa Tamansari}

Partisipasi dan pembangunan merupakan konsep yang saling berhubungan. Untuk program pembangunan desa wisata, tahapan partisipasi yang digunakan adalah tahap perencanaan, tahap pelaksanaan, dan tahap pengawasan atau evaluasi.

Tabel 23 Hasil nilai signifikansi tahap perencanaan, pelaksanaan, dan pengawasan/evaluasi dengan tingkat pembangunan desa

\begin{tabular}{|c|c|}
\hline $\begin{array}{l}\text { Partisipasi } \\
\text { Masyarakat }\end{array}$ & $\begin{array}{c}\text { Tingkat } \\
\text { Pembangunan Desa }\end{array}$ \\
\hline Tahap Perencanaan & $0.316^{*}$ \\
\hline Tahap Pelaksanaan & $0.369^{*}$ \\
\hline Tahap Pengawasan & $0.450 * *$ \\
\hline
\end{tabular}

Tabel 23 menunjukkan bahwa terdapat hubungan yang signifikan antara variabel. Jumlah dan persentase hubungan berdasarkan partisipasi responden dengan tingkat pembangunan desa pada masyarakat di Desa Tamansari disajikan pada Tabel 24. Berdasarkan Tabel 24, tingkat pada tahap perencanaan, pelaksanaan, dan pengawasan memiliki hubungan yang signifikan terhadap tingkat pembangunan desa wisata hal tersebutdikarenakan pembangunan desa tidak akan berjalan tanpa adanya partisipasi masyararakat. Hasil dari uji korelasi hubungan antar variebel menunjukan hasil yang signifikan karena nilai Sig.(2-sided) atau p-value lebih kecil dari taraf nyata yaitu $\alpha=0,05$ dan $\alpha=0,01$. 
Tabel 24 Jumlah dan persentase responden menurut karakteristik individu dan tingkat faktor pendorong partisipasi pembangunan Desa Tamansari

\begin{tabular}{|c|c|c|c|c|c|c|c|c|c|}
\hline \multicolumn{2}{|c|}{ Karakterisitik Individu } & \multicolumn{8}{|c|}{ Tingkat Faktor Pendorong Partisipasi } \\
\hline & & \multicolumn{2}{|c|}{ Rendah } & \multicolumn{2}{|c|}{ Sedang } & \multicolumn{2}{|c|}{ Tinggi } & \multicolumn{2}{|c|}{ Total } \\
\hline & & $\mathrm{n}$ & $\%$ & $\mathrm{n}$ & $\%$ & $\mathrm{n}$ & $\%$ & $\mathrm{n}$ & $\%$ \\
\hline \multirow[t]{4}{*}{ Tahap Perencanaan } & Rendah & 16 & 66.7 & 2 & 8.3 & 6 & 25.0 & 24 & 100.0 \\
\hline & Sedang & 4 & 26.6 & 7 & 43,8 & 5 & 31.3 & 16 & 100.0 \\
\hline & Tinggi & 0 & 0.0 & 3 & 100.0 & 0 & 0.0 & 3 & 100.0 \\
\hline & Total & 20 & 46.5 & 12 & 27.9 & 11 & 25.6 & 43 & 100.0 \\
\hline \multirow[t]{4}{*}{ Tahap Pelaksanaan } & Rendah & 1 & 100.0 & 0 & 0.0 & 0 & 0.0 & 1 & 100.0 \\
\hline & Sedang & 10 & 71.4 & 2 & 14.3 & 2 & 1.34 & 14 & 100.0 \\
\hline & Tinggi & 9 & 32.1 & 10 & 36.7 & 9 & 32.1 & 28 & 100.0 \\
\hline & Total & 20 & 46.5 & 12 & 27.9 & 11 & 25.6 & 43 & 100.0 \\
\hline \multirow[t]{4}{*}{ Tahap Pengawasan } & Rendah & 15 & 52.2 & 8 & 33.3 & 1 & 4.2 & 24 & 100.0 \\
\hline & Sedang & 4 & 28.6 & 1 & 7.1 & 9 & 54.3 & 14 & 100.0 \\
\hline & Tinggi & 1 & 20.0 & 3 & 60.0 & 1 & 20.0 & 5 & 100.0 \\
\hline & Total & 20 & 46.5 & 12 & 27.9 & 11 & 25.6 & 43 & 100.0 \\
\hline
\end{tabular}

\section{SIMPULAN DAN SARAN}

\section{Simpulan}

Dari penelitian tentang modal sosial dan partisipasi masyarakat dalam pembangunan desa wisata di Desa Tamansari, dapat disimpulkan bahwa modal sosial yang dimiliki masyarakat termasuk ke dalam kategori tinggi. Hal tersebut dikarenakan tingginya kepercayaan yang dimiliki diantara masyarakat ataupun pihak lain, tingginya norma yang dimiliki oleh masyarakat sehingga menciptakan hubungan yang baik di antara masyarakat Desa Tamansari, dan tingginya jaringan karena dijadikannya Desa Tamansari sebagai desa wisata memberikan manfaat kepada masyarakat. Faktor pendorong partisipasi termasuk ke dalam kategori tinggi. Masyarakat memiliki kemauan, kesempatan, dan kemampuan untuk dapat terlibat dalam upaya pembangunan desa wisata. Tingkat partisipasi masyarakat termasuk ke dalam kategori sedang. Mereka kurang diikutsertakan dalam tahapan perencanaan dan pengawasan. Partisipasi masyarakat dalam tahapan pelaksanaan termasuk ke dalam kategori tinggi dan masyarakat sangat antusias dalam membangun Desa Tamansari sebagai desa wisata.

Tingkat pembangunan desa termasuk ke dalam kategori rendah. Hal itu karena manfaat yang diterima masyarakat belum merata dan belum banyak program-program yang belum direalisasikan. Tingkat kapasitas diri yang dimiliki masyarakat termasuk ke dalam kategori tinggi. Masyarakat mendapatkan peningkatan kemampuan untuk berinteraksi dan menambah kemampuan berbahasa asing dengan adanya pelatihan-pelatihan yang diadakan. Sementara itu, tingkat pendapatan termasuk dalam kategori rendah karena tidak semua masyarakat mendapatkan peningkatan pendapatan yang sama. Semua tergantung kepada jasa yang mereka tawarkan.

Hasil yang didapatkan dari pengukuran hubunganhubungan yang terjadi diantara variabel yang diuji statistik non-parametrik menggunakan uji Rank Spearman. Hasil penelitian menunjukan terdapat terdapat hubungan yang lemah pada variabelvariabel yang diuji. Hubungan yang kuat hanya terjadi pada hubungan antara partisipasi masyarakat dengan tingkat pembangunan desa wisata di Desa Tamansari. Hal tersebut dikarenakan masyarakat merupakan faktor utama dalam pembangunan, sehingga berhasil atau tidaknya suatu pembangunan berada pada masyarakat itu sendiri.

\section{Saran}

1. Perlu dilibatkannya masyarakat dalam tahapan perencanaan serta pengawasan pembangunan desa, agar masyarakat mengetahui dan dapat menyumbangkan ide atau gagasan mereka dalam pembangunan desa wisata tersebut. Tahapan perencaaan dan tahapan pengawasan pembangunan desa wisata akan berjalan lebih baik, sehingga menyesuaikan dengan kebutuhan masyarakat serta potensi desa dan sejalan dengan tingkat pelaksanaan masyarakat yang sudah baik.

2. Perlu adanya peningkatan motivasi masyarakat agar mereka dapat secara mandiri mencari 
potensi yang dapat dikembangkan di daerah mereka, dan perlu dilakukannya pengawasan ataupun evaluasi secara berkala dari berbagai pihak terkait seperti pihak BCA, BUMDes, dan masyarakat.

\section{DAFTAR PUSTAKA}

Alfitri. 2011. Community Development Teori dan Aplkasi. Yogyakarta : Pustaka Pelajar.

Ariyani I. 2007. Penguatan partisipasi masyarakat dalam program imbal swadaya di Desa Curug Kecamatan Gunung Sindur Kabupaten Bogor.[Tesis]. Bogor [ID]: Institut Pertanian Bogor.120 hal.

Cahyono B, Adiathma A. 2012. Peran modal social dalam peningkatankesejahteraan petani tembakau di Kabupaten Wonosobo. CBAM: Conference prosiding, 01(01): 131-144. [internet]. [diunduh tanggal 4 Oktober 2016 pukul 07.45]. Dapat diunduh dari http:/jurnal.unissula.ac .id/index.php/cbam/article/ view/128/104

Dewi MHU, Chafid F, M Baiquni. 2013. Pengembangan desa wisata berbasispartisipasi masyarakat lokal di Desa Wisata Jatiluwih Tabanan Bali. Jurnal Kawistara, 03(02): 129-139. [internet]. [diunduh tanggal 4 Januari 2012 pukul 08.45]. Dapat diunduh dari https://journal.ugm.ac.id/ kawistara/article/ download/3976/3251

Handoyo E. 2013. Kontribusi modal sosial dalam meningkatkan kesjahteraanpedagang kaki lima pascarelokasi. Komunitas : Jurnal Research and Learning in Sociology and Anthropology, 05(03): 253-266. [internet]. [diunduh tanggal 4 Oktober 2016 pukul 07.30. Dapat diunduh dari: http://journal.unnes.ac.id/artikel_nju/ komunitas/2743

Harris $G$ dan Vogel D. 2004. E-Commerce for Community-Based Tourism in Developing Countries [internet]. [diunduh 2 Maret 2016]. Dapat diunduh dari: http://rogharris .org/eCBT.pdf

Harsono W. 2014.Jimpitan, Modal Sosial yang Menjadi Solusi Permasalahan Masyarakat. JKAP: Jurnal Kebijakan dan Administrasi Publik, 18(02): 131146. [internet]. [diunduh tanggal 4April 2016 pukul 07.45]. Dapat diunduh dari : https://journal.ugm.ac.id/jkap/ article/view/7518/5848

Kartasasmita G. 1994. Manajemen Pembangunan Untuk Negara Berkembang. Jakarta: PT Gelora Aksara Pratama

Khayati R. 2016. Hubungan Modal Sosial Komunitas dengan Persepsi danPartisipasi Aktivitas Budaya. [skripsi]. Bogor: Departemen Sains Komunikasi dan Pengembangan Masyarakat, Fakultas Ekologi Manusia, Instutut Pertanian Bogor.

Lugiarti E. 2004. Peningkatan Partisipasi Masyarakat dalam Proses Perencanaan Program Pengembangan Masyarakat di Komunitas Desa Cijayanti. [Tesis]. Sekolah Pascasarjana. Institut Pertanian Bogor.

Masik A. 2005. Hubungan modal sosial dengan perencanaan. Jurnal Pembangunan, 16(03): 1-23. [internet]. [diunduh tanggal 4 Oktober 2016 pukul 16.20. Dapat diunduh dari : http://www.sappk.itb.ac.id/jpwk/wpcontent /uploads/ 2014/01/VOL16-NO3-1.pdf

Nasdian FT. 2006. Pengembangan Masyarakat.Bogor: Institut Pertanian Bogor.

Nasdian FT. 2004. Pengembangan Masyarakat.Bogor: Institut Pertanian Bogor.

Setiawan N. 2007. Penentuan ukuran sampel memakai rumus slovin dan table krejcieomorgan: telah konsep dan aplikasinya.[internet]. [diunduh tanggal 4 Februari 2017 pukul 16.50].Dapat diunduh dari : http://www.academia. edu/16612066/Penentuan_ukuran_sampel_memak rumus slovin

Oktavia S, Saharuddin. 2013. Hubungan Peran Stakeholders dengan Partisipasi Masyarakat dalam Program Agropolitan Desa Karacak Kecamatan Leuwiliang Kabupaten Bogor. Jurnal [internet]. [diunduh tanggal 4 Oktober 2016 pukul 16.25].Vol01No 03.Dapatdiunduhdari: http:// journal.ipb.ac.id/index.php/sodality/article/view/9 407/7371

Siagian SP. 1994. Teori dan Praktek Kepemimpinan. Jakarta: Rhineka Cipta.

Singarimbun M, Effendi S. 2014. Metode Penelitian Survai. Jakarta (ID): PT Pustaka LP3ES Indonesia. Slamet M. 2003. Membentuk Pola Perilaku Manusia Pembangunan. Bogor:IPB Press

Wicaksono TN. 2016. Hubungan Modal Sosial dan Partisipasi Kepengurusan dengan Taraf Hidup Anggota Program Pengembangan Uasaha Agribisnis Pedesaan. [skripsi]. Bogor: Departemen Sains Komunikasi dan Pengembangan Masyarakat, Fakultas Ekologi Manusia, Instutut Pertanian Bogor 
Puspitaningrum \& Lubis / Jurnal Sains Komunikasi dan Pengembangan Masyarakat 2(4):465-484

484 - Agustus 2018 